\title{
Simulation Based Energy Consumption Optimization for Buildings by Using Various Energy Saving Methods
}

Omar Khaled Barakat ${ }^{1}$, Ahmed El-Biomey Mansour ${ }^{1}$, Mahmoud Mohamed Abd Elrazik ${ }^{2}$, Ashraf Aboshosha ${ }^{3}$, Amir Yassin Hassan $^{4, *}$

${ }^{1}$ Department of Electrical Engineering, Faculty of Engineering, Al-Azhar University, Cairo, 11651, Egypt

${ }^{2}$ Building physics Institute, Housing and Building National Research Center, Giza, 12511, Egypt

${ }^{3}$ Department of Radiation Engineering, NCRRT, Atomic Energy Authority, Nasr City, Cairo, 11651, Egypt

${ }^{4}$ Department of Power Electronics and Energy Conversion, Electronics Research Institute, Giza, 12511, Egypt

\section{A R T I C L E I N F O}

Article history:

Received: 23 September, 2020

Accepted: 04 December, 2020

Online: 21 December, 2020

Keywords:

Energy efficiency

Power saving

Smart grid

Design builder software
A B S T R A C T

The world has turned in the modern era to reduce peak times for electricity consumption, where the peak times cause excessive load on the electricity grid and power stations. In Egypt air conditioning loads are considered the main contributing reasons for the peak time's problem due to presence of large unshaded glazed surfaces, which cause high thermal loads inside the buildings. In this study, various methods of energy rationalization in buildings are evaluated by using many scenarios, from the obtained results of this research study. It is found that the use of shading on windows is an effective strategy where the percentage of rationalization using scenarios integration reached $40 \%$, and the financial returns have also been calculated based on this work.

Nomenclature

\begin{tabular}{clcl}
\hline AHU & Air Handling Unit & LED & Light Emitting Diodes \\
BMS & Building Management System & PF & Power Factor Correction \\
CVRMSE & Coefficient of Variation of Root Mean Squared Error & SHGC & Solar Heat Gain Coefficient \\
DB & Design Builder & THD & Total Harmonic Distortion \\
GUI & Graphical User Interface & VFD & Variable Frequency Drive \\
HVAC & Heating, Ventilation, and Air Conditioning Systems & VSD & Variable Speed Drive \\
\hline
\end{tabular}

\section{Introduction}

The rise of $4 \mathrm{G}$ industry era in our nowadays life led to a great demand of efficient energy systems specially the requirements of the large-scale industrial systems. This led to a significant rise in electricity prices; therefore energy conservation became a crucial policy [1]. It is an influential reason for preserving the environment and climate [2]. Therefore the world has turned to energy efficiency [3]. With the continuous development of technology, the smart home applications appeared in its contribution to improve energy efficiency effectively. As the smart grid deals with the flow of energy in distribution networks whose objectives are to balance supply and demand [4]. The more energy transfers from one form to another, the more losses occur. With the increasing of

*Corresponding Author: Amir Yassin Hassan, 33 El-Tahrir st., Dokki, Giza, Egypt., Email: amir@eri.sci.eg

www.astesj.com

https://dx.doi.org/10.25046/aj0506178 energy transformations, it is found a reduced gab between production and the consumer also an increase in the efficiency of devices and equipment, the loss decreases, the consumption be more efficient, rationalization increases and helps in reducing the demand for increased power plants [5].

Energy management is the assessment and measurement of electrical energy consumption in buildings [4]. As the global economy develops, it is necessary to strengthen and improve research and development in building energy management. The association of energy classification methods in new buildings is also necessary to develop building policies that are of great importance. Therefore, the main functions of energy management systems are to monitor, control and improve energy flow in general [6]. Energy management systems start from the use of energy- 
saving devices, through smart buildings to supervisory control applications [7].

Energy auditing is also a review and evaluation of building energy use and identification of energy saving measures to reduce consumption [6]. This is through the analysis of public service bills such as electricity bills [4]. Throughout this framework a professional power saving protocol is applied to reduce the electrical energy consumption in public buildings. This protocol includes - but not limited to - power factor correction, variable speed control, earth leakage current treatment, lighting management, heating, ventilation, and air conditioning (HVAC) system, load management and intelligent energy system. Correction of power factor has many economic benefits, one of those, is saving the financial fine that the electricity company imposes when the power factor drops below 0.90 [8], [9]. Technically, it reduces the overload on transformers and generators and reduces the overload on cables and switches [10]. The variable speed drive (VSD) and frequency speed drive (VFD) when used in the Air Handling Unit (AHU), it can save energy up to $18 \%$ and save energy at least $7.5 \%$ when used in Chiller pumps [10], [11]. Earthing leakage current treatment is obtained by isolating cables and conductors according to the Egyptian code for electrical installations and connections in buildings. Assuming that the ground leakage current in a residential or administrative unit is $30 \mathrm{~mA}$, this means that the monthly energy loss is about 4.75 kilowatt hours [8].

The use of light emitting diodes (LED) bulbs technology, which is considered an improvement in lamp efficiency, leads to limited energy savings, but when maximizing daylight, it is one of the measures to achieve a low energy design [12]. Also, a study was conducted to study the effect of changing the power factor in the LED bulbs on the total harmonic distortion (THD), the study was conducted on a house and a hotel, and the result was that it contributes to increasing harmonics [13]. As well as in another study on the effect of changing the feeding voltage of the LED bulbs (160-240) volts on the quality of the bulb and the color characteristics of the bulb, it was found that the bulb of good and approved industry is not affected by this change [14]. A comparison of the LED bulbs feeding was done with a constant voltage (DC) and a variable voltage (AC) and the result was that the lamp efficiency increased from $5 \%$ to $10 \%$ in the case of feeding using DC more than AC [15]. Also, two of the typical methods for achieving effective energy management and lighting control are working to integrate natural and industrial lighting or using highly efficient bulbs [16].

HVAC systems are responsible for the occupants 'comfort in the building by saving internal temperature, humidity, and the total air quality inside the building. Therefore, they are responsible for a large part of the building's energy consumption [17]. It is noted that the use of technological developments increased the efficiency of HVAC systems and thus reduced energy consumption, for example, the use of automatic natural ventilation by using suction fans and automatic windows. When a strong wind or storm occurs, it closes automatically [17]. Various concepts and elements have been developed to reduce energy use for cooling and heating in buildings [16] Such as:
- Mixed method: Use natural ventilation when the external temperature is moderate and use mechanical if necessary.

- Air distribution system: there are fans that work when there are people to reduce the thermal loads inside the building. Therefore, it is noted that the application of this system in the German commercial bank building, Commerzbank, where the architect Norman Foster has used [16]:

Natural lighting from the surrounding windows with hinges and can be opened and shaded by a Building Management System (BMS) system.

Natural ventilation for approximately $60 \%$ of the total hours of use, and mechanical ventilation is used in extreme conditions. There is also a system for night ventilation where the temperature is moderate in summer for pre-cooling of the thermal mass and the possibility of using the heat switch for the ground and groundwater.

\section{Methodology}

The research aim is the possibility of using simulation programs to determine the energy consumption per square meter annually, whether the building is finished or in the design stage and Economic study of the methods of rationalization in the simulation program and the application of the most feasible method in practice. The workflow of this study will be structured as follows:

- Determining the study case to implement the energy rationalization mechanism.

- Preliminary evaluation of the case study using smart electricity meters.

- Evaluating using the DB simulation program with studying the following:

- The effect of rationalization on change the Set Point of the Cooler device on consumption rationalization.

- Effect of rationalization in lighting.

- Rationalization by fixed shading.

- The effect of rationalization in glass types on the rationalization of energy.

- The effect of rationalization in the use of thermal insulation.

- presenting of simulation results for rationalization scenarios.

- Making a Comparison between actual consumption and results of simulation program consumption (DB) and then calculating the error.

- Discussing the rationalization scenarios used in the study.

- Evaluation of the economic return.

\section{Model Description}

Air conditioning engineers ASHRAE (the Energy Accounts Committee) completed a new project in the late 1990's to create mathematical algorithms that can be used for various building models (including the contents of a building's cover, appliances, and equipment in the building).It is also available to the simulation community [18]. Therefore, the Design Builder (DB) program is an easy-to-use design environment that helps in designing the construction model. Therefore, it loads heating, cooling and 
lighting calculations using heat. Likewise, energy conservation indicators, annual consumption, thermal comfort indicators, temperature and humidity, heat transfer from walls and windows, air leakage and architectural shading calculations can be analyzed every hour and a study of rationalization methods more efficiently and with high accuracy [19]. DB is a GUI for Energy plus [20].

The case study was chosen on the western front of building of the National Center for Housing and Building Research, which is a government administrative building located in Giza Governorate, as shown in Table 1 and Figures 1 and 2 . That by selecting the case that contains lighting and air conditioning loads only as shown in Table 1. As well as working hours start from $8 \mathrm{Am}$ in the morning until $5 \mathrm{Pm}$ in the afternoon.

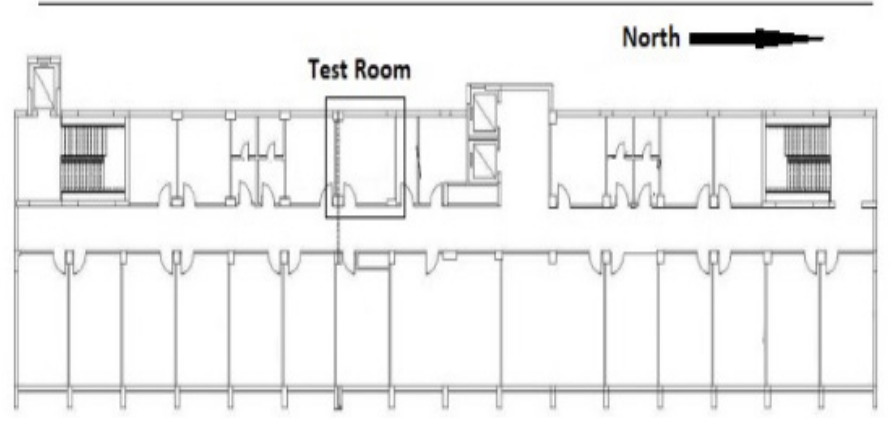

Figure 1: Case Study Location

Table 1: General Description of the Case Study

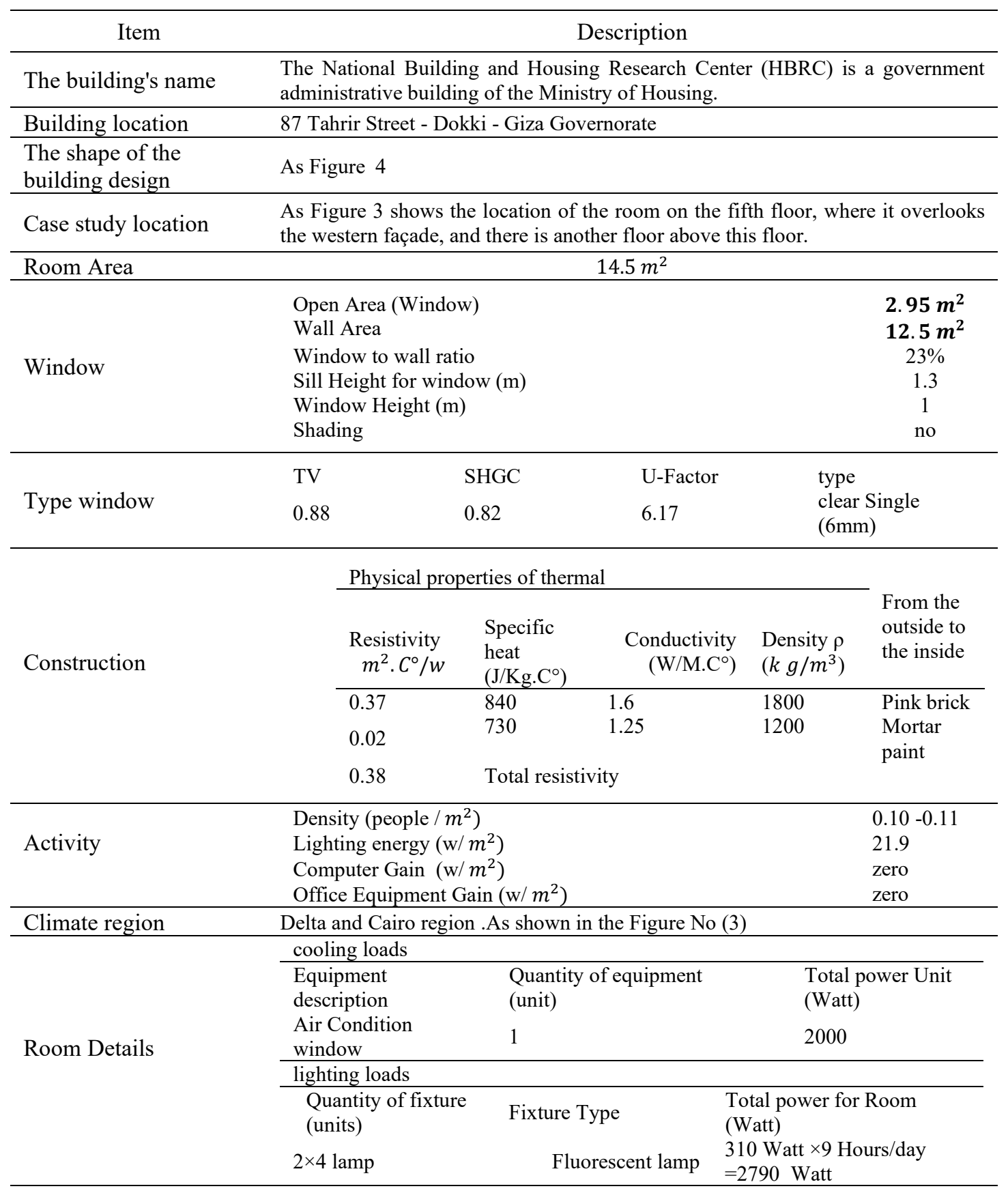




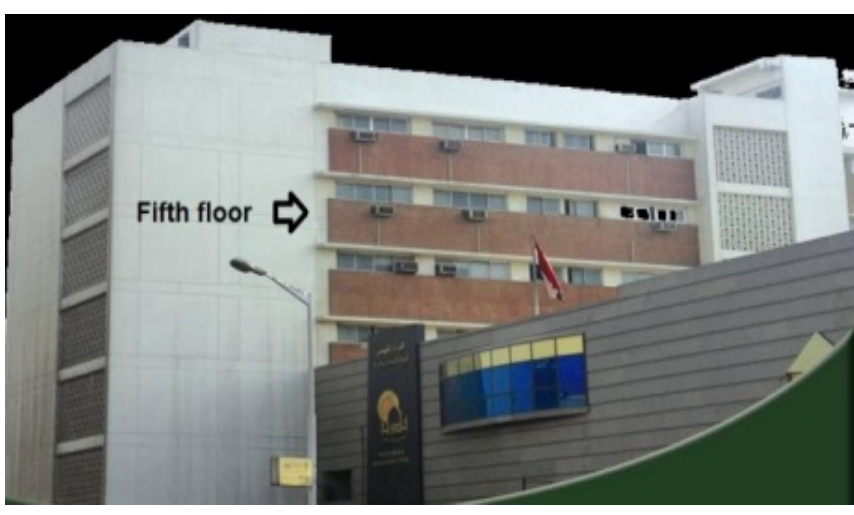

Figure 2: The Building Design

\section{Simulation Results}

\subsection{Modeling and Validation Check}

Case study simulation was done on DB program as shown in Figure 3. The validity of the simulation program was also confirmed by comparison between the simulation program results and the laboratory measurement of the energy consumption of the air conditioner by a smart open source electricity meter that measures every half a second and maintains these measurements in a built-in memory as shown in Figure 4. Also, the smart meter measurement was also compared with a certified clamp meter measurement and the error rate was $0.02 \%$. As for lighting consumption, it was constant throughout working hours. Laboratory measurements of air conditioning loads were done on August 25, 2019 (8Am - 5Pm) and the measurement was done without using shading. Also on September 4, using 55\% fixed shading. The beginning of laboratory registration was from 10 in the morning until 5 in the afternoon. Therefore, Table 2 Shows the result of comparison and the error rate between the simulation program and the laboratory measurement. From equation 1 the error associated with the energy models may be declared valid the CVRMSE within $\pm 30 \%$ when using hourly data or $5 \%$ to $15 \%$ when using monthly data [20].

$$
\text { CVRMSE }=100 \times \frac{\sqrt{\left(\overline{\left.\bar{Y}_{\text {measured }}-Y_{\text {modelled }}\right)^{2}}\right.}}{\bar{Y}_{\text {measured }}}
$$

Where, $\mathrm{Y}_{\text {measured }}$ is the measure data point, $\mathrm{Y}_{\text {modelled }}$ is the modeled data point and $\bar{Y}_{\text {measured }}$ is the average of all measured data points.

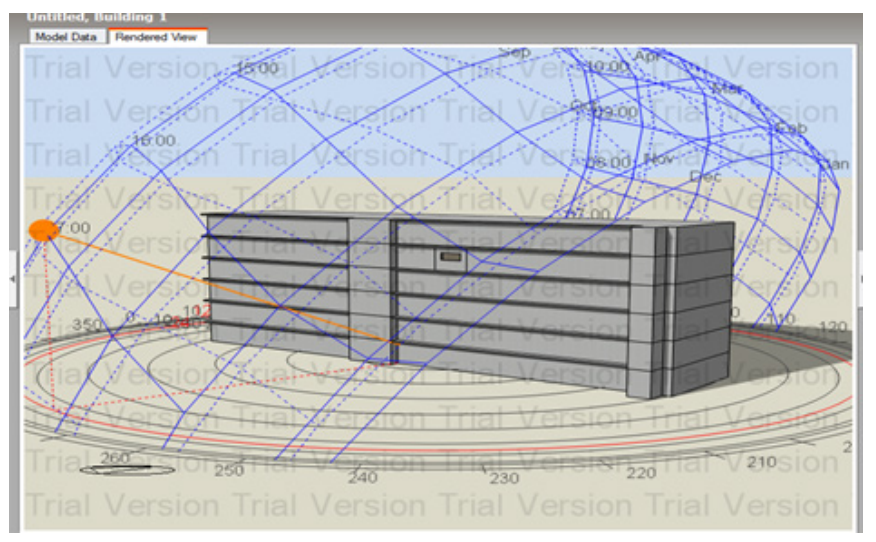

Figure 3: The Building Modeling in the Simulation Program

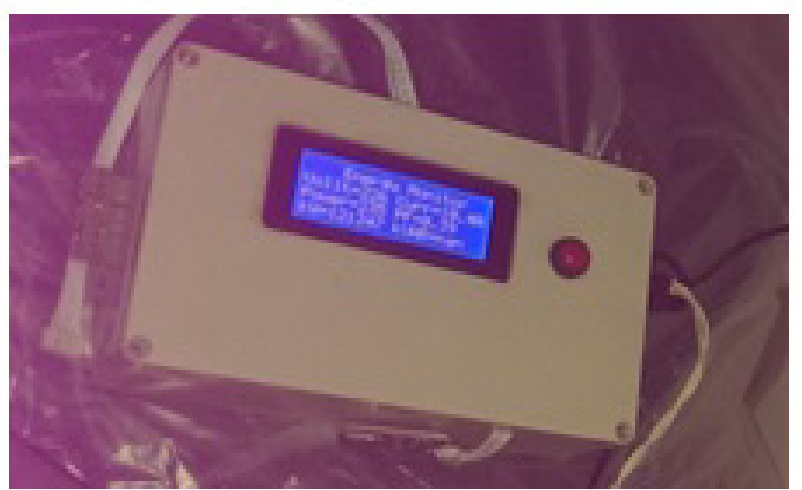

Figure 4: The Smart Electricity Meter for Measuring and Recording Energy

Table 2: The Error Percentage between Simulation and Laboratory Measurement

\begin{tabular}{cccc}
\hline Time & $\begin{array}{c}\text { Error } \\
(\%)\end{array}$ & $\begin{array}{c}\text { Simulation Air } \\
\text { condition } \\
\text { consumption } \\
(\mathrm{KW})\end{array}$ & $\begin{array}{c}\text { actual Air } \\
\text { condition } \\
\text { consumption } \\
(\mathrm{KW})\end{array}$ \\
\hline $\begin{array}{c}\text { Total Daily } \\
(8 \mathrm{Am}- \\
5 \mathrm{Pm})\end{array}$ & $1.46 \%$ & 22.74572 & 22.4177 \\
& & &
\end{tabular}

\subsection{Simulation result with the basic case}

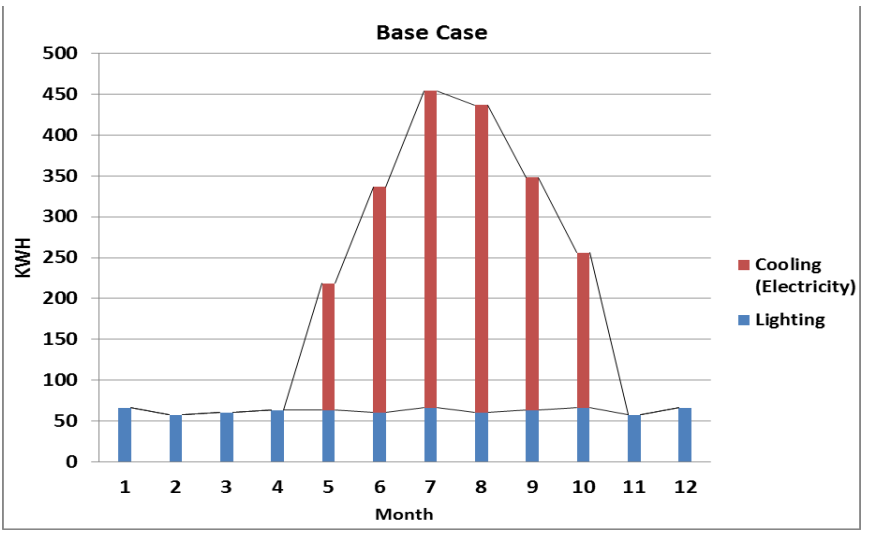

Figure 5: The Monthly Consumption of the Basic Case

Table 3: The Annual Consumption with the Basic Study Case

\begin{tabular}{ccc}
\hline Month & Lighting (KWh) & Cooling (KWh) \\
\hline 1 & 66.22 & 0 \\
2 & 57.58 & 0 \\
3 & 60.46 & 0 \\
4 & 63.34 & 0 \\
5 & 63.34 & 155.30 \\
6 & 60.46 & 275.82 \\
7 & 66.22 & 387.90 \\
8 & 60.46 & 376.13 \\
9 & 63.34 & 284.59 \\
10 & 66.22 & 190 \\
11 & 57.58 & 0 \\
12 & 66.22 & 0 \\
Summation & 751.50 & 1669.78 \\
Total & & 2421.29
\end{tabular}




\subsection{Simulation Result of the Consumption Rationalization by} Changing the Set Point of the Air Conditioning Device:

Table 4 and Figure 6 illustrate the electricity consumption while simulating with changing the Set Point of the air conditioning device.

Table 4: The Electrical Energy Consumption for Each Set Point

\begin{tabular}{cccccc}
\hline NO & $\begin{array}{c}\text { Set } \\
\text { point } \\
\left({ }^{\circ} \mathrm{c}\right)\end{array}$ & $\begin{array}{c}\text { Total } \\
(\mathrm{KWH})\end{array}$ & $\begin{array}{c}\text { Consumptio } \\
\text { n increase } \%\end{array}$ & $\begin{array}{c}\mathrm{CO} 2 \\
\text { increas } \\
\mathrm{e}\end{array}$ & $\begin{array}{c}\mathrm{kwh} / \mathrm{m} \\
2\end{array}$ \\
\hline 1 & $21^{\circ} \mathrm{C}$ & $\begin{array}{c}3357.3 \\
8\end{array}$ & $38.66 \%$ & $38.66 \%$ & 230 \\
2 & $22^{\circ} \mathrm{C}$ & $\begin{array}{c}3078.3 \\
5\end{array}$ & $27.14 \%$ & $27.14 \%$ & 211 \\
3 & $23^{\circ} \mathrm{C}$ & $\begin{array}{c}2808.1 \\
8\end{array}$ & $15.98 \%$ & $15.98 \%$ & 193 \\
4 & $24^{\circ} \mathrm{C}$ & $\begin{array}{c}2548.4 \\
0\end{array}$ & $5.25 \%$ & $5.25 \%$ & 175 \\
5 & $24.5^{\circ}$ & $\begin{array}{c}2421.2 \\
9\end{array}$ & $0.00 \%$ & $0.00 \%$ & 166
\end{tabular}

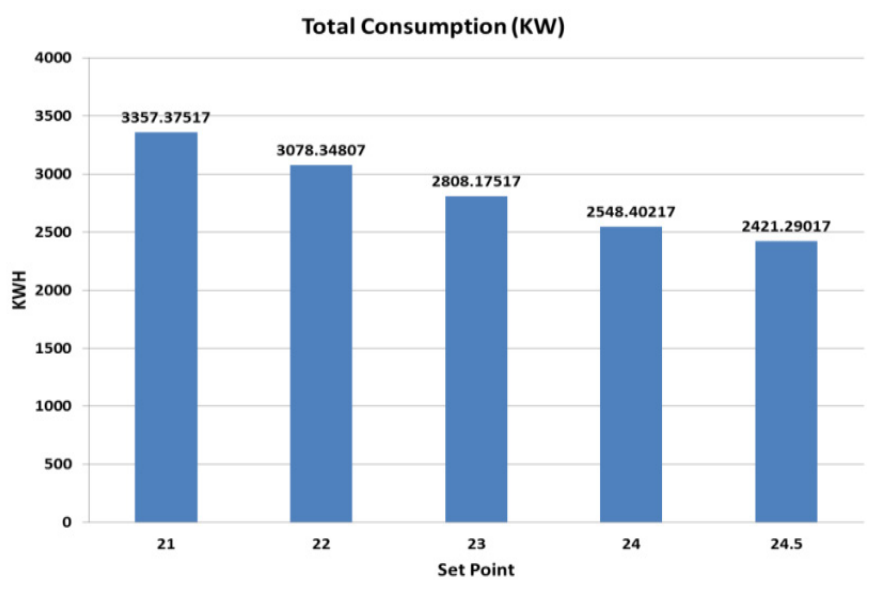

Figure 6: The Electrical Energy Consumption at Set Point

\subsection{Simulation Result of the Consumption Rationalization by Lighting Control}

Table 5 and Figure 7 show the electricity consumption while simulating with rationalization by lighting control.

Table 5: The Ratios of Rationalization Using Lighting Control Systems

\begin{tabular}{|c|c|c|c|c|}
\hline NO. & $\begin{array}{c}\text { Type of Saving } \\
\text { use }\end{array}$ & $\mathrm{KWh} / \mathrm{m}^{2}$ & $\begin{array}{c}\mathrm{Co}_{2} \\
\text { saving }\end{array}$ & $\begin{array}{l}\text { Rationalization } \\
\text { rate }\end{array}$ \\
\hline 1 & $\begin{array}{l}\text { STEPED } \\
\text { Controller }\end{array}$ & 98.15 & $40.9 \%$ & $40.9 \%$ \\
\hline 2 & $\begin{array}{l}\text { Linear } \\
\text { Controller }\end{array}$ & 115.93 & $30.2 \%$ & $30.2 \%$ \\
\hline 3 & LED & 113.81 & $31.5 \%$ & $31.5 \%$ \\
\hline 4 & LED+SENSOR & 100.36 & $39.6 \%$ & $39.6 \%$ \\
\hline
\end{tabular}

\subsection{Simulation Result of the Consumption Rationalization by \\ Changing the Glass Type}

Table 6 and Figure 8 indicate the simulation results while using rationalization by changing the glass type.

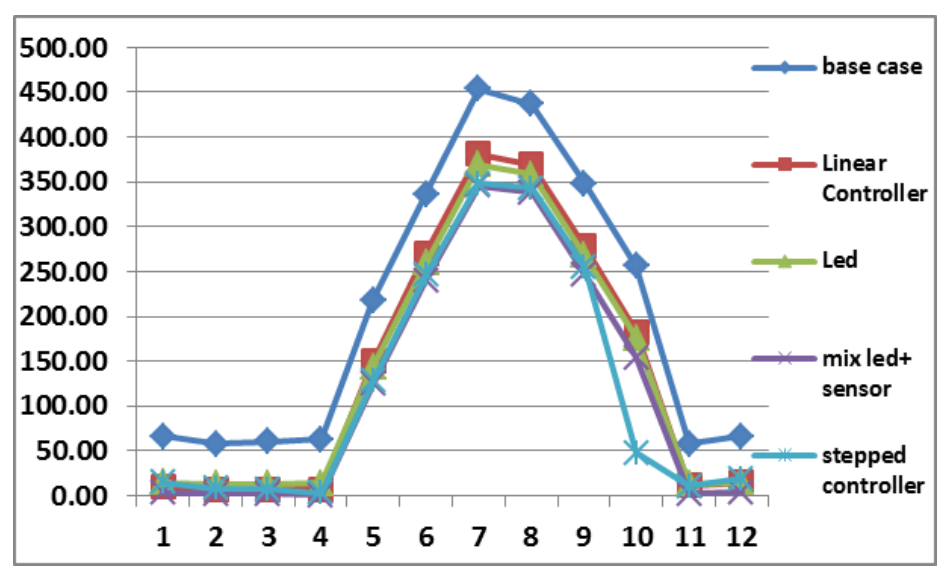

Figure 7: Simulation Results in Electrical Energy Consumption for Each Type of Lighting Control

Table 6: The Simulation Results in Electrical Energy Consumption for Each Type of Glass Used

\begin{tabular}{cccc}
\hline Item & $\begin{array}{c}\text { Single( base } \\
\text { case) }\end{array}$ & $\begin{array}{c}\text { Dbl Blue } \\
6 \mathrm{~mm} / 13 \mathrm{~mm} \\
\text { Air }\end{array}$ & $\begin{array}{c}\text { Thin film car } \\
\text { core }\end{array}$ \\
\hline Annual (KWh) & 2421.29 & 2271.1611 & 2144.1506 \\
SHGC & 0.83 & 0.497 & 0.28 \\
Rationalization & - & $6.3 \%$ & $11.6 \%$ \\
rate \% & - & $6.3 \%$ & $11.6 \%$ \\
Co2 saving \% & - & &
\end{tabular}

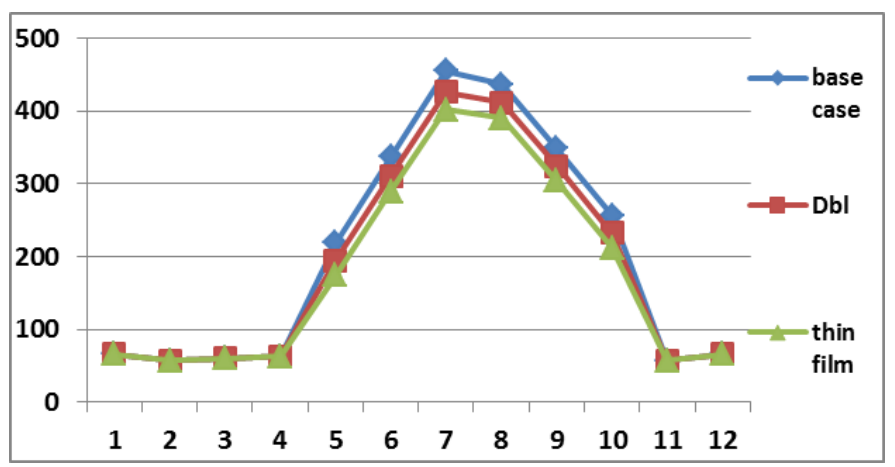

Figure 8: The Simulation Results in Electrical Energy Consumption for Each Type of Glass Used

4.6. Simulation Result of the Consumption Rationalization Using Thermal Insulation of Facade Walls

Table 7 and Figure 9 show the simulation results of rationalization with thermal insulation of facade walls.

Table 7: The Cooling Consumption Based on Wall Resistance

\begin{tabular}{cc}
\hline $\mathrm{R}$ & Cooling $(\mathrm{KWh})$ \\
\hline 0.26 & 1815 \\
0.292 & 1556 \\
0.31 & 1501 \\
0.32 & 1485 \\
0.339 & 1485 \\
0.35 & 1497 \\
0.39 & 1561 \\
1 & 1724 \\
2.853 & 1907.3216
\end{tabular}




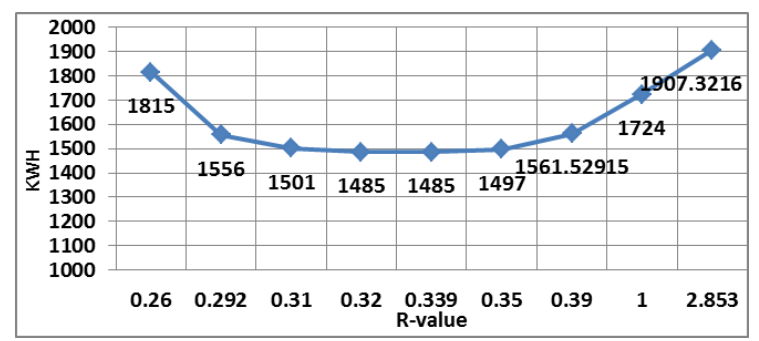

Figure 9: The Energy Consumption Using Thermal Insulation

\subsection{Simulation Result of the Consumption Rationalization by Using Shading Control}

Table 8 and Figure 10 illustrate the simulation result swith shading control.

Table 8: The Rationalization Scenarios Using Shading Methods

\begin{tabular}{|c|c|c|c|c|}
\hline No. & $\begin{array}{l}\text { The type of } \\
\text { shading used }\end{array}$ & $\mathrm{KWh} / \mathrm{m}^{2}$ & $\begin{array}{c}\mathrm{CO} 2 \\
\mathrm{~kg} / \mathrm{kWh} \\
\text { equiv. }\end{array}$ & $\begin{array}{l}\text { rationalization } \\
\text { percentage }\end{array}$ \\
\hline 1 & $\begin{array}{c}\text { base case } \\
\text { vertical shading }\end{array}$ & 166 & - & - \\
\hline 2 & $\begin{array}{c}\text { When the } \\
\text { window } \\
\text { shading ratio } \\
55 \%\end{array}$ & 143 & $14.1 \%$ & $14.1 \%$ \\
\hline & $\begin{array}{c}\text { High } \\
\text { reflectance - }\end{array}$ & & & \\
\hline 3 & $\begin{array}{c}\text { low } \\
\text { transmittance } \\
\text { shade }\end{array}$ & 156 & $\% 6.0$ & $\% 6.0$ \\
\hline 4 & $\begin{array}{l}\text { Drapes - closed } \\
\text { weave light }\end{array}$ & 162 & $\% 2.3$ & $\% 2.3$ \\
\hline 5 & $\begin{array}{l}\text { Blind with high } \\
\text { reflectivity slats }\end{array}$ & 161 & $3.2 \%$ & $3.2 \%$ \\
\hline 6 & $\begin{array}{l}\text { Transparent } \\
\text { insulation }\end{array}$ & 164 & $1.3 \%$ & $1.3 \%$ \\
\hline 7 & $\begin{array}{l}\text { Electrochromic } \\
\text { reflective } 6 \mathrm{~mm}\end{array}$ & 158 & $4.9 \%$ & $4.9 \%$ \\
\hline 8 & $\begin{array}{l}\text { horizontal fixed } \\
\text { shading } 1.0 \mathrm{~m} \\
\text { horizontal fixed }\end{array}$ & 149 & $10.5 \%$ & $10.5 \%$ \\
\hline 9 & $\begin{array}{l}\text { shading } 1.0 \mathrm{~m} \\
\text { and From both } \\
\text { sides } 1.0 \mathrm{~m}\end{array}$ & 147 & $11.7 \%$ & $11.7 \%$ \\
\hline 500 & & & & - - base case \\
\hline $\begin{array}{l}450 \\
400\end{array}$ & & & & -vertical shading $55 \%$ \\
\hline 350 & & & & lectance \\
\hline 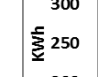 & & & & $\begin{array}{l}\text { Drapes - closed weave } \\
\text { light }\end{array}$ \\
\hline $\begin{array}{l}200 \\
150\end{array}$ & & & & $\begin{array}{l}\text { - Blind with high } \\
\text { reflectivity slats }\end{array}$ \\
\hline $\begin{array}{r}100 \\
50\end{array}$ & 늘 -1 & & 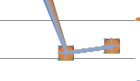 & $\begin{array}{l}\text { Electrochromic } \\
\text { reflective } \mathrm{mmm}\end{array}$ \\
\hline & $1 \quad 2$ & & & $\begin{array}{l}\text { horizontal fixed } \\
\text { shading } 1.0 \text { and } \\
\text { From both sides } 1.0 \mathrm{~m}\end{array}$ \\
\hline
\end{tabular}

Figure 10: The Rationalization Scenarios Using Shading Methods www.astesj.com

\subsection{Simulation Result with Integration of Rationalization Methods}

Table 9 and Figure 11 show the simulation result with integration of rationalization methods (mix $1-\operatorname{mix} 2-\operatorname{mix} 3)$

Table 9: Integrations Between Scenarios

\begin{tabular}{cccc}
\hline Scenarios Integration & $\begin{array}{c}\text { saving } \\
\%\end{array}$ & $\mathrm{KWh} / \mathrm{m}^{2}$ & $\begin{array}{c}\text { Payback } \\
\text { period } \\
\text { (Year) }\end{array}$ \\
\hline $\begin{array}{c}\text { Led } \\
\text { mix1 (Led +Daylight }\end{array}$ & $31.5 \%$ & 114 & 1.1 \\
sensor) & $39.6 \%$ & 100 & 3.6 \\
Mix2 (Led +shading 55\%) & $43.0 \%$ & 95 & 3.4 \\
mix3 (Led + Day light & $50.5 \%$ & 82 & 5.1 \\
sensor+ shading 50\%) & & &
\end{tabular}

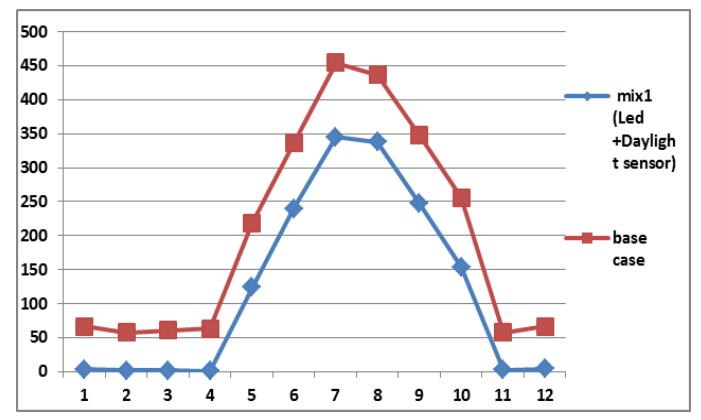

Figure 11: (a) Simulation Result for Comparison Between Total Consumption for Base Case and When Using Integration mix 1 (Led + Daylight Sensor)

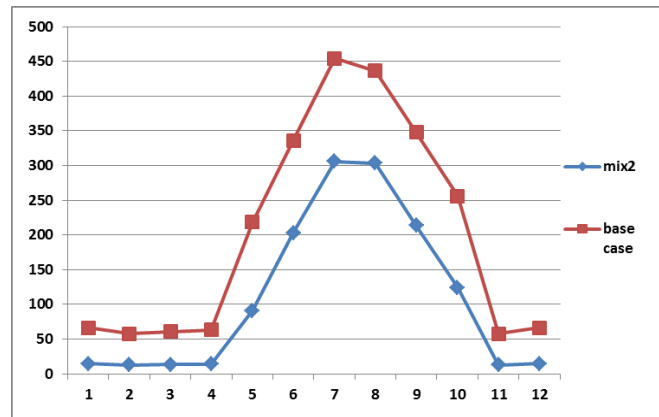

Figure 11: (b) Simulation Result for Comparison Between Total Consumption for Base Case and When Using Integration mix 2 (Led + Vertical Shading at $55 \%$ ).

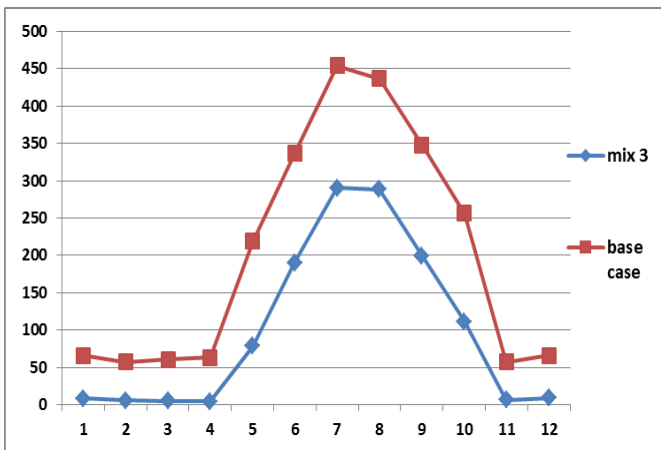

Figure 11: (c) Simulation result for Comparison between Total Consumption for Base Case and When Using Integration mix 3 (Led + Day Light Sensor + Vertical Shading at 55\%) 


\section{Discussions}

\subsection{Electricity Consumption for the Basic Case}

After making the comparison and proving the error rate within the mathematically allowed, an annual consumption of the research study, shown in Figure 5 and Table 3, has been made. Also, it was taken into consideration that this case uses air conditioning in the period of 6 summer months, starting from May to October only. As for the lighting consumption, it is used throughout the year, and it turns out that the average consumption of electrical energy is $166 \mathrm{KWh} / \mathrm{m}^{2}$. Where also by calculates the emission of carbon dioxide due to consumption $1383.8 \mathrm{Kg} \mathrm{CO} 2-\mathrm{eq}$ $/ \mathrm{kWh}$ considering that each kilowatts consumption is 0.57151 $\mathrm{kgCo} 2$ [21]. Also for calculate the emissions per square meter is $94.9 \mathrm{~kg}-\mathrm{CO} 2-\mathrm{eq} / \mathrm{m} 2$.

\subsection{The Effect of Set Point Change of Air Conditioning Device on the Rationalization of Energy Consumption}

The effect of electrical consumption when using Set point for the air conditioning device on the following temperatures has been studied: $\left(21^{\circ} \mathrm{c}-22^{\circ} \mathrm{c}-23^{\circ} \mathrm{c}-24^{\circ} \mathrm{c}-24.5^{\circ} \mathrm{c}\right)$. Table 4 shows the electrical consumption for each Set Point. Therefore, it was found that setting the temperature to $24.5^{\circ} \mathrm{C}$ saves energy consumption $38 \%$ compared to setting the temperature at $21^{\circ} \mathrm{C}$ as in Figure 6. Therefore, it is considered one of the best rationalization and not expensive. The annual consumption of the base case was also calculated by setting the temperature to $24.5^{\circ}$.

\subsection{The Effect of Lighting Control on the Rationalization of Energy Consumption}

In this case, the daylight factor was suitable. Therefore, the focus was on using rationalization by replacing fluorescent bulbs into low-watt LED bulbs [22]. Also, using a daylight sensor using the Step 1 method, as there is only one office in the case study, and from Table 5 it was found that rationalization of changing old lamps to LED technology saves $31 \%$ of the total consumption. Also, rationalization using a daylight sensor saves $36 \%$, as in Figure 7.

\subsection{The effect of glass types on the rationalization of energy consumption}

Table 6 shows a study of rationalization in consumption by reducing solar heat gain coefficient (SHGC). Also in Figure 8, it is noted that the lower the SHGC, the lower consumption.

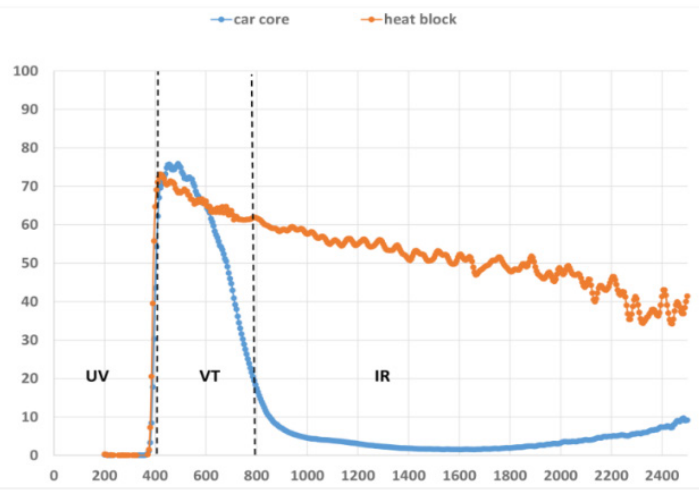

Figure 12: A Thin Film Car Core Characteristic
Also, with advanced technology, day by day, the focus will be on making materials that reduce SHGC and increase the visible transmission light as shown in Figure 12 for a thermoforming glass sample that shows its ability to reduce SHGC and increase the visible transmission light.

\subsection{The Effect of Thermal Insulation on the Rationalization of Energy Consumption}

From Table 7 it was found that using insulation in the western facade increases the energy consumption in summer due to the heat retention within the research study. Also Figure 9 shows the best resistance of the external wall

\subsection{The Effect of Shading Control on the Rationalization of Energy Consumption}

Figure 10 and Table 8 show the scenarios for rationalization by shading. Therefore, it was found that vertical shading by $55 \%$ as in Figure 13 of the window area is better in rationalization than horizontal and vertical shading on both sides of the window length of $1 \mathrm{~m}$. Vertical shading is characterized by having a motor that can control the rate of openings for windows. Therefore, it is possible to maximize the benefit of the sun in winter and increase shading in summer. Also, observed decrease of the value of the flowing current in the wire was $14 \%$.Also, the reason for choosing $55 \%$ shading is because at this point the lighting intensity was measured at the desktop level by lux meter in 4-sept -2019 during working hours (8am - 5pm) and the minimum was 300 lux. Accordingly, this shading was bought as in the Figure 13 and it is controlled according to occupant's desire. As lighting consumption constant, sureness of simulation program validity is by comparison of electric energy consumption that resulted from cooling as in the table 10

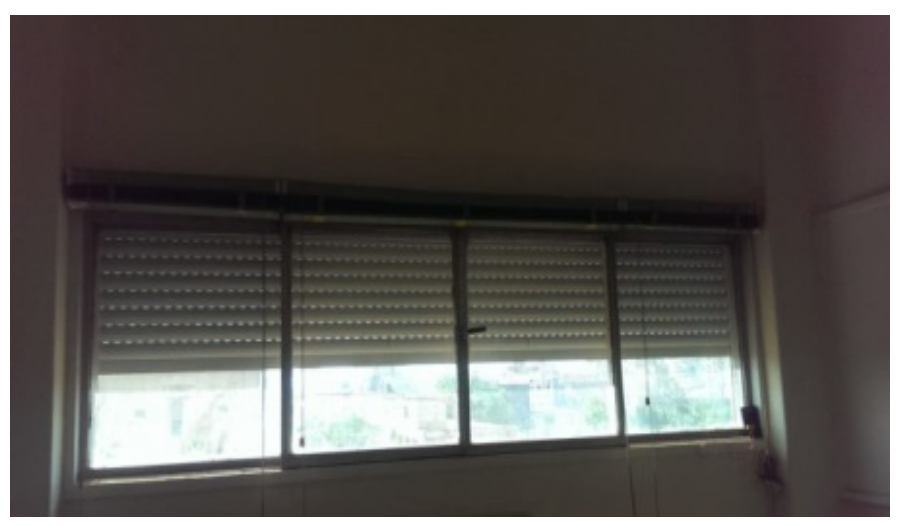

Figure 13: 55\% Shading During the Summer Period

Table 10: The Comparison Between The Readings Recorded in the Simulation Program and Measured by Smart Meter

\begin{tabular}{cccr}
\hline Time & $\begin{array}{c}\text { Simulation } \\
(\mathrm{KWH})\end{array}$ & $\begin{array}{c}\text { Measure } \\
(\mathrm{KWH})\end{array}$ & Error \% \\
\hline 10 a.m. & 2.312434 & 2.21625 & $5.16 \%$ \\
11 a.m. & 1.775199 & 1.5 & $14.76 \%$ \\
12 p.m. & 1.708757 & 1.575 & $7.17 \%$ \\
1 p.m. & 1.681947 & 1.8375 & $8.34 \%$ \\
2 p.m. & 1.725026 & 1.8 & $4.02 \%$ \\
3 p.m. & 1.72124 & 2.0625 & $18.30 \%$ \\
4 p.m. & 1.704831 & 2.0625 & $19.18 \%$ \\
Total & 12.629434 & 13.05375 & $3.3 \%$ \\
& & & 1486
\end{tabular}




\subsection{The Effect of Integration on the Rationalization of Energy Consumption and Return on Investment (ROI)}

Table 9 shows the methods of integration, the percentage of rationalization in each scenario, and the period for recovering capital from the energy saving (Assuming electricity tariff in Egypt is $1.5 \mathrm{EGP} / \mathrm{kWh}$ ), the more integration scenarios of rationalization, the greater the savings rate as in Figure 11. It can be noted that the non-use of photovoltaic energy due to our approaching to the lowest station that can be connected to the distribution network in Egypt is 5 kilowatts. Therefore, it is not economically feasible in this case. The economic feasibility to rationalization can be measured by the following equation [18]:

Expected payback period

$$
=\frac{\text { initial cost }+ \text { operation and maintenance costs }}{\text { cost operation saving }}
$$

\section{Conclusion}

Optimizing the utilization of energy in buildings tends to save more power. The "Design Builder" simulation program is used for simulating the study building. In this paper, various energy saving methods are used to optimize the energy consumption in buildings. It can be found that the more integration between saving scenarios, the higher economic return. The behaviour of occupants poses a great challenge in implementing the rationalization methods. It can be noted that the percentage of rationalization that reached is large, that is due to lighting and air-condition loads only. Controlling the temperature of the refrigeration device represents the more simple and effective rationalization method with low cost and significant rationalization ratio. Also it is recommended to replace old bulbs with high efficiency bulbs because they have an economic return and reduce the consumption of cooling loads indirectly. Also rationalization can be achieved by the use of shading and lighting control using the daylight sensor. Shading helps in converging the average electrical energy consumption in the summer and winter seasons, as well as helps in reducing the consumed power by the air conditioners. Rationalization in air conditioning loads helps in achieving a balance in the average monthly consumption during the year where an annual energy saving about $39.6 \%$ is achieved. Comparison between the simulation results and the measured results shows that the simulation program can be reliable in studying the economic feasibility of rationalization scenarios before implementation.

\section{Conflict of Interest}

The authors declare no conflict of interest.

\section{Acknowledgment}

Special thanks to Electronics Research Institute and the National Center for Housing and Building Research.

\section{References}

[1] M.H.M. Alham, Optimal operation of electric power systems considering wind power uncertainty incorporating energy storage system and demand side management, Ph.D. thesis, Cairo Universty, 2016.

[2] P.A. Owusu, S. Asumadu-Sarkodie, "A review of renewable energy sources, sustainability issues and climate change mitigation," Cogent Engineering, 3(1), 1-14, 2016, doi:10.1080/23311916.2016.1167990.

[3] M.A. Tovar Reaños, N.M. Wölfing, "Household energy prices and inequality: Evidence from German microdata based on the EASI demand system," Energy Economics, 70, 84-97, 2018, doi:10.1016/j.eneco.2017.12.002.

[4] N. Bin Ishak, Energy management practices and implementation in campus building, Master Thesis, University Malaysia Pahang, 2016.

[5] T. Davis, J.Hanania, K. Stenhouse, L.Vargas Suarez, J. Donev, Energy loss, Energyeducation, 2015.

[6] S.K. Singh, B.K. Tiwari, A.K. Pandey, "Energy conservation: Analysis improvement through energy audit," 3rd International Conference on Innovative Applications of Computational Intelligence on Power, Energy and Controls with Their Impact on Humanity, CIPECH 2018, 203-209, 2018, doi:10.1109/CIPECH.2018.8724220.

[7] B. Zhou, W. Li, K.W. Chan, Y. Cao, Y. Kuang, X. Liu, X. Wang, "Smart home energy management systems: Concept, configurations, and scheduling strategies," Renewable and Sustainable Energy Reviews, 61, 30-40, 2016, doi:10.1016/j.rser.2016.03.047.

[8] HBRC, Egyptian Code for Improving Energy Efficiency in Commercial Buildings, Egypt, 2017.

[9] EEHC, Annual Report of Egypt Electricity 2017/2018, The Egyptian Electricity Holding Company, Ministry of Electricity and Renewable Energy, Egypt, 2018.

[10] K. Braun, E. Eaves, C. Giambri, D. Chapman, H. Heavner, J. Woodward, J. Nagel, K. Gipson, "Reducing electrical energy consumption of AHU fans through the integration of variable frequency drives," 2016 IEEE Systems and Information Engineering Design Symposium, SIEDS 2016, 61-65, 2016, doi:10.1109/SIEDS.2016.7489328.

[11] A. Kasman, W. Ruslan, W. Basuki, "Performance Analysis of Chiller System," International Journal of Applied Engineering Research ISSN 0973$4562,14(13), 3017-3021,2019$.

[12] M. Ljubenovic, P. Mitkovic, B. Stojanovic, M. Ignjatovic, J. Janevski, P. Zivkovic, "Intelligent Skin and Occupancy in the Context of Increasing Energy Efficiency in Buildings," ANNALS of Faculty Engineering Hunedoara - International Journal of Engineering, 201-208, 2018.

[13] M.S. Islam, N.A. Chowdhury, A.K. Sakil, A. Khandakar, A. Iqbal, H. AbuRub, Power quality effect of using incandescent, fluorescent, CFL and LED lamps on utility grid, 2015 1st Workshop on Smart Grid and Renewable Energy, SGRE, 2015, doi:10.1109/SGRE.2015.7208731.

[14] I.A.V. Damanik, N.I. Sinisuka, "The effect of voltage variation (160-240volt) on lighting quality and color properties of LED lamps in Indonesia," 2016 3rd IEEE Conference on Power Engineering and Renewable Energy, ICPERE 2016, 179-183, 2016, doi:10.1109/ICPERE.2016.7904865.

[15] A. Jhunjhunwala, K. Vasudevan, P. Kaur, B. Ramamurthi, Kumaravel, S. Bitra, K. Uppal, "Energy efficiency in lighting: AC vs DC LED lights," 2016 1st IEEE International Conference on Sustainable Green Buildings and Communities, SGBC 2016, 7-10, 2016, doi:10.1109/SGBC.2016.7936068.

[16] M. sanusi, A. abd alghani, "The use of modern technologies Technologies for Developing Banks Buildings in Egypt", International Journal in Architecture, Engineering and Technology, "(article in Arabic)", Egypt, 2018, doi:10.21625/baheth.v1i1.192.

[17] B. Tetik, Energy performance of smart buildings: simulating the impact of active systems and passive strategies, Master's thesis, Pontificia Universidad Catolica del Peru, 2014.

[18] A.M.A. Abbady, Improvement of thermal energy efficiency of office buildings by integration of passive and active, Master's thesis, Cairo University, Egyp, 2019.

[19] Team DesignBuilder, DesignBuilder v6 Simulation Documentation, DesignBuilder program, 2019.

[20] J. Anderson, Modelling and performance evaluation of net zero energy buildings, Master's thesis, University of Wollongong, 2016.

[21] Egyptian Electric Utility and Consumer Protection Regulatory Agency (EgyptERA), Electricity report monthly, EgyptERA, EGYPT, 2020.

[22] The Ministry of Electricity and Renewable Energy in Egypt, Energy Efficiency for Lighting \& Appliances Project in egypt, MOEE, Egypt, 2017. 